\title{
Review and a New Species of the African Genus Acanthiops (Ephemeroptera : Baetidae)
}

\author{
H. M. Barber-James ${ }^{1}$ \\ W. P. McCafferty 2
}

Keywords : Ephemeroptera, Baetidae, Acanthiops, Africa, Acanthiops tsitsa.

The African genus Acanthiops Waltz and McCafferty (Ephemeroptera : Baetidae) is reviewed, redescribed, and figured. The genus is a monophyletic group, easily identified in the larval stage by its distinctive labium, dorsal abdominal armature, claw armature, and two-tailed condition. A previous synonymy of Afroptilum (subgenus Afroptiloides) Gillies with Acanthiops is corroborated. Nominal species included in Acanthiops are A. marlieri (Demoulin) from Zaire, $A$. tsitsa $\mathrm{n}$. sp. from South Africa, $A$. variegatus (Gillies) n. comb. from Tanzania, and $A$. varius (Crass) from South Africa. There are other undescribed species more widespread in sub-Saharan Africa. Species vary considerably and express relative apotypy in development of dorsal armature. Acanthiops tsitsa is described from larvae taken in the North East Cape; it is related to A. varius, but differs in dorsal armature and mouthpart characterization.

\section{Revue du genre africain Acanthiops, avec la description d'une espèce nouvelle (Ephemeroptera : Baetidae)}

Mots clés : Ephemeroptera, Baetidae, Acanthiops, Africa, Acanthiops tsitsa.

Le genre Africain Acanthiops Waltz et McCafferty (Ephemeroptera : Baetidae) est revu, redécrit et figuré. Ce genre est un groupe monophylétique, facilement identifiable à la phase larvaire par des caractères distinctifs touchant le labium, les tubercules médians des tergites abdominaux, les griffes, et par la présence de deux cerques. La synonymie précédente d'Afroptilum (sousgenre Afroptiloides) Gillies avec Acanthiops est corroborée. Les espèces nominales rangées dans Acanthiops sont $A$. marlieri (Demoulin) du Zaïre, $A$. tsitsa n. sp. d'Afrique du Sud, A. variegatus (Gillies) n. comb. de Tanzanie, et $A$. varius (Crass) d'Afrique du Sud. Des espèces non décrites sont répandues en Afrique, au Sud du Sahara. Les espèces varient considérablement et montrent une relative-apotypie dans le développement des tubercules médiodorsaux. Acanthiops tsitsa est décrite à partir de larves provenant du Nord-Est de la province du Cap; elle est apparentée à $A$. varius, mais en diffère par les tubercules dorsaux et les pièces buccales.

\section{Introduction}

When Gillies (1990) transferred the African species that häd been historically assigned to Centroptilum Eaton to his new genus Afroptilum Gillies, he also divided it into two subgenera : Afroptilum s.s. and Afroptiloides Gillies. Afroptilum sudafricanum (Lestage) was designated the type of the genus, and $A$. varium (Crass) was designated the type species of the subgenus Afrop-

1. Albany Museum, Somerset Street, Grahamstown 6140, South Africa.

2. Department of Entomology, Purdue University, West Lafayette, IN 47907, USA. tiloides. McCafferty and de Moor (1995) moved this latter species to the genus Acanthiops Waltz and McCafferty, and by so doing essentially synonymized Afroptiloides with Acanthiops. The reason for this action was not stated by McCafferty and de Moor (1995); however, it was done on the basis of data that suggested the type of Afroptiloides was only distantly related to the type of Afroptilum, and instead shared a most recent common ancestor with the type of Acanthiops, $A$. marlieri (Demoulin). Nevertheless, because this information has not been made available before now, and because $A$. marlieri is one of the most specialized, apotypic species of Baetidae in Africa, we herein present a comprehensive description of Acanthiops. We show that Acanthiops is a monophyletic genus with several gradational species, including a new species described 
from South Africa. We also show why Afroptiloides and its previously assigned species cannot stand as a separate taxon within the context of a strictly phylogenetic classification.

\section{Acanthiops Waltz and McCafferty}

Acanthiops Waltz and McCafferty, 1987 : 97.

Afroptiloides Gillies, 1990 : 99, n. syn.

\subsection{Description}

Larva

- HEAD

Labrum (Fig. 10) variously indented apicomedially.

Right mandible (Fig. 8) with incisors separated; prostheca slender; setal patch present.

Left mandible (Figs. 9, 16) with incisors fused; prostheca stout; setal patch present; molar thumb well developed and elevated above plane of incisor bases; well developed molar area.

Maxillae (Figs. 12, 14) with short, two-segmented palpus, never extending much beyond galealacinia.

Hypopharynx (Fig. 11) with marginal setae; lingua produced somewhat apicomedially.

Labium (Fig. 13) with glossae and paraglossae similar in size and subequal in length; terminal segment of palpi reduced, rounded to narrowly rounded apically, narrower than subapical palpal segment (being inset bilaterally compared with distal width of subapical segment).

\section{- THORAX}

Pro- and mesonotum [Figs. 1, 2, Fig. 3 of Demoulin (1967)] with or without paired tubercles; metanotum with or without tubercles or spines.

Legs [Figs. 1, 6, Fig. 3 of Demoulin (1967)] without femoral villopore; tibiae with or without dorsal row of hairlike setae; claws with pair of subapical, bristlelike setae, and with two rows of short denticles (Fig. 15).

\section{- ABDOMEN}

Body somewhat dorsoventrally depressed.

Abdominal segments [Figs. 1, 2, Figs. 7, 8 of Gillies (1991a)] each with mediodorsal process (small tuberclelike to large and spinelike) on terga 1-9, sometimes poorly developed on 1,8 or 9 , or absent on 1 or 9 ; segments not posterolaterally developed; terga with or without scales and fine setae.

Gills [Figs. 1, 5, Fig. 4 of Demoulin (1967)] slightly to greatly asymmetrical and slightly to greatly overlapping. Cerci (Figs. 1,7) with or without hairlike setae along inner margin.

Median caudal filament reduced, not cercus-like.

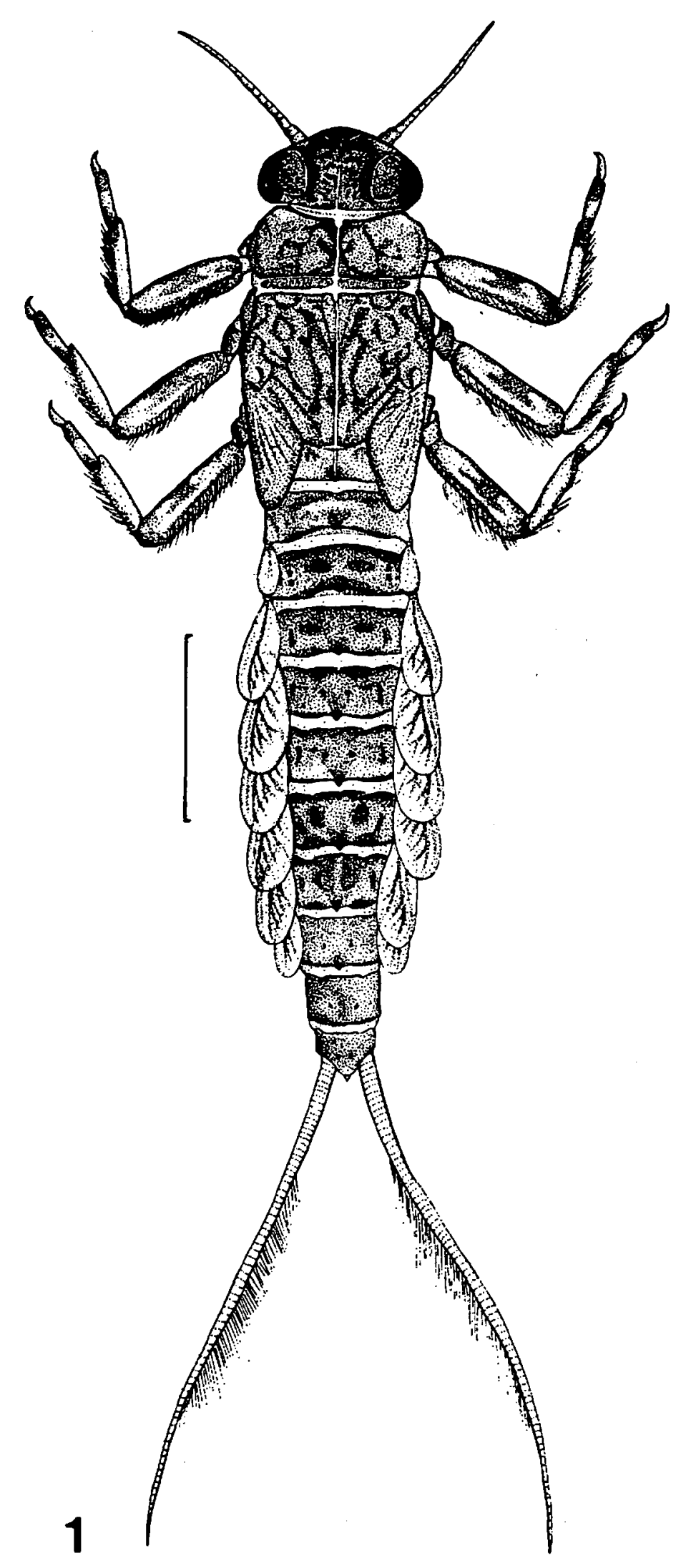

Fig. 1. Acanthiops tsitsa n. sp., whole larva (dorsal) (échelle $=1 \mathrm{~mm}$ ).

Fig. 1. Acanthiops tsitsa n. sp., vue d'ensemble dorsale de la larve (scale line $=1 \mathrm{~mm}$ ). 

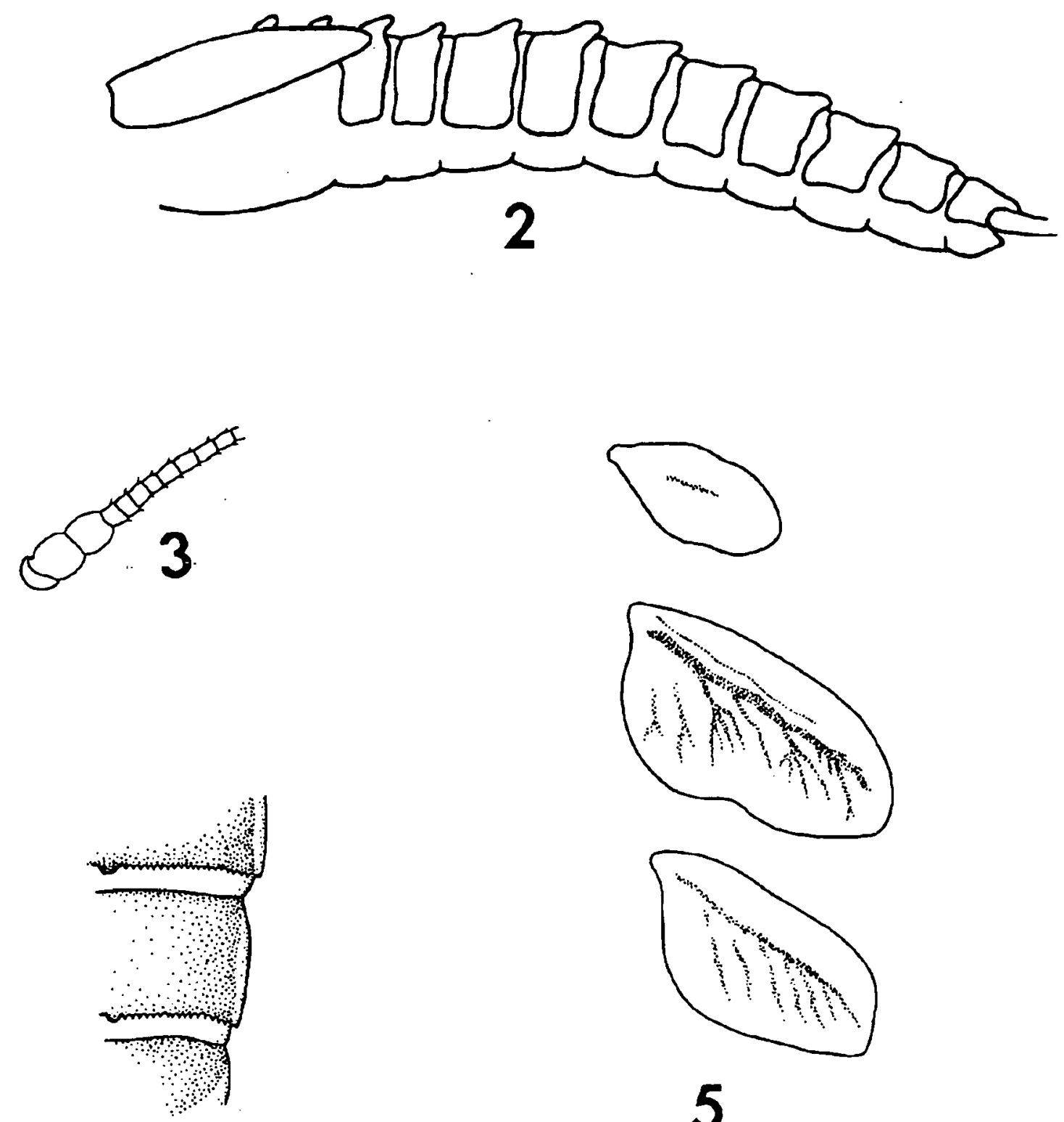

5
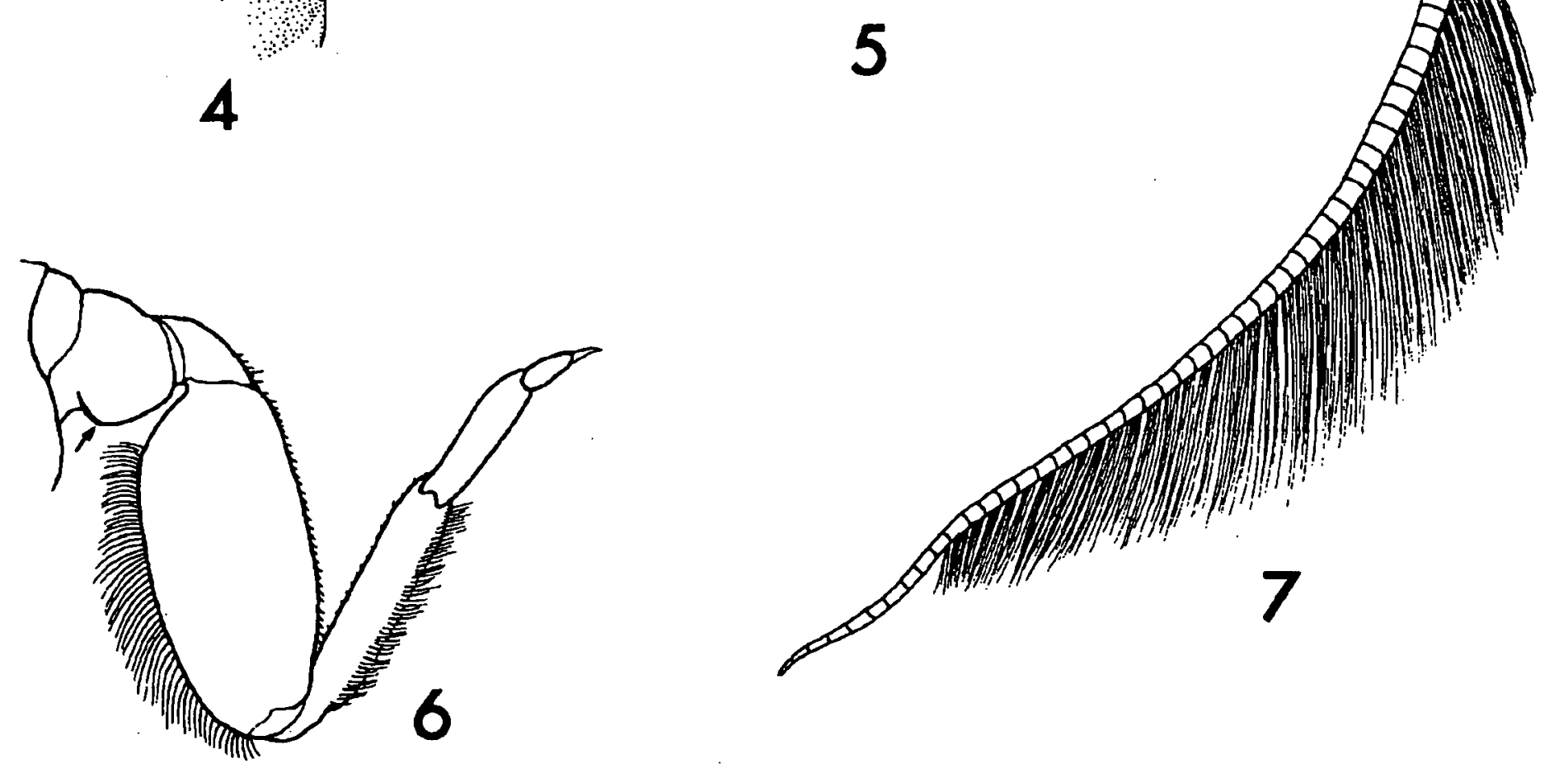

Figs. 2-7. Acanthiops tsitsa n. sp., larva. 2 : Abdomen, lateral view. $3:$ Antenna, showing minute spinelike setae. $4:$ Abdominal terga VII, VIII, and IX. 5 : Gills I, III and V. 6 : Foreleg, viewed from lateral angle; arrow indicates expanded lobe on coxa. $7:$ Cercus (left, dorsal), with details of setae.

Figs. 2-7. Larve d'Acanthiops tsitsa n. sp. 2 : Abdomen en vue latérale. $3:$ Antenne et ses soies en écailles. $4:$ Tergites abdominaux VII, VIII et IX. 5 : Branchies I, III et V. 6 : Patte antérieure en vue latérale oblique; la flèche indique l'expansion coxale. $7:$ Cerque gauche en vue dorsale, avec détail des soies. 
Adult

\section{- THORAX}

Forewings [Fig. 9 of Gillies (1991a)] with single marginal intercalaries. Hindwings present; known hindwings [Fig. 25 of Crass (1947), Fig. 10 of Gillies (1991a)] with two or three longitudinal veins and no crossveins; costal process nonbifurcate, acute, and somewhat hooked.

\section{- ABDOMEN}

Abdomen with or without vestiges of larval dorsomedial processes. Male genitalia [Fig. 25 of Crass (1947), Fig. 12 of Gillies (1991a)] with three-segmented forceps; terminal forceps small, narrow-teardrop shaped.

\subsection{Diagnosis}

The combination of the distinctively reduced terminal labial palpal segment and subequal glossae and paraglossae (Fig. 13); the double row of claw denticles and the pair of bristles near the end of the claws (Fig. 15); the dorsal abdominal armature [Fig. 2, Fig. 3 of Demoulin (1967), Figs. 7, 8 of Gillies (1991a)]; and the two-tailed condition will easily distinguish this genus from others. Only two of the species are known in the adult stage, and therefore adult generic description and diagnosis are preliminary. If all adults of Acanthiops prove to possess a non-bifurcate costal process in the hindwings, this would be of some diagnostic significance. Most of those species historically known as Centroptilum (a rather large grouping in Africa among those baetid mayflies with single marginal intercalaries in the forewings) possess the bifurcate costal process.

\subsection{Type species}

Centroptilum marlieri Demoulin, 1967 : 230.

\subsection{Species included}

Acanthiops marlieri (Demoulin), A. tsitsa n. sp., A. variegatus (Gillies) n. comb., and A. varius (Crass). A number of unnamed species throughout much of Africa apparently belong to Acanthiops as summarized by Gillies (1991a) under the name Afroptiloides.

\subsection{Distribution}

Sub-Saharan Africa, with known records thus far from Ethiopia (undescribed sp.), Guinea (undescribed sp.), Malawi (undescribed sp.), South Africa, Tanzania, Uganda (undescribed sp.), and Zaire.

\subsection{Discussion}

Defining synapomorphic larval character states that we propose for Acanthiops include the symmetrically reduced, rounded, and centered terminal labial palp segment (Fig. 13); the double row of denticles on the claws (Fig. 15); and the distinctive medial armature of the abdominal terga (Fig. 2). The development of long, apical, bristlelike setae on each claw (Fig. 15) may also represent a synapomorphy, but we cannot be entirely sure of this because a similar characteristic is present in several genera that are believed to represent more plesiotypic lineages of Baetidae (R. D. Waltz, personal communication).

As is almost always the case in lineages of Baetidae, they must be defined by a combination of characters, and the useable synapomorphies are subject to homoplasy in an array of unrelated lineages within the family. The condition described for the terminal labial palpal segment in Acanthiops is uncommon but is also found in at least two undescribed and unrelated genera of baetids in both South America and Africa (LugoOrtiz and McCafferty, in manuscript). A similar type of labial palp is also present in A. sudafricanum. The fact that $A$. sudafricanum does not share any other synapomorphies with Acanthiops, including those listed above as well as those found in $A$. sudafricanum but not Acanthiops (e.g., paraglossae that are broader than the glossae, and a bifurcate costal process in the hindwings) suggests to us that such a reduced palp has evolved convergently in those lineages. There is, however, a slight possibility that the two lineages share an ancestor with such a palp. Double rows of claw denticles are found convergently in disparate lineages of Baetidae, for example, in the genera Harpagobaetis Möl, Centroptiloides Lestage, and Waltzoyphius LugoOrtiz and McCafferty; and medial dorsal tuberculation is found convergently in such unrelated baetids as Echinobaetis Möl, some species of Baetiella Ueno, Baetodes Needham and Murphy, and Gratia Thomas. Despite the profusion of homoplasy in Baetidae, any one of the synapomorphies we propose for Acanthiops, if originating independently in an immediate common ancestor of the included species, would cladistically validate our classification.

There is an apparent progression in the degree of dorsal armature development in the species of Acanthiops. Dorsal abdominal tubercles are smallest in the South African species $A$. tsitsa $\mathrm{n}$. sp. and A. varius, become larger in size in the Tanzanian A. variegatus, are even larger and more extensive in some undescribed species [e.g., that illustrated by Kimmins (1955) from Malawi], and finally reach their extreme as long spines 

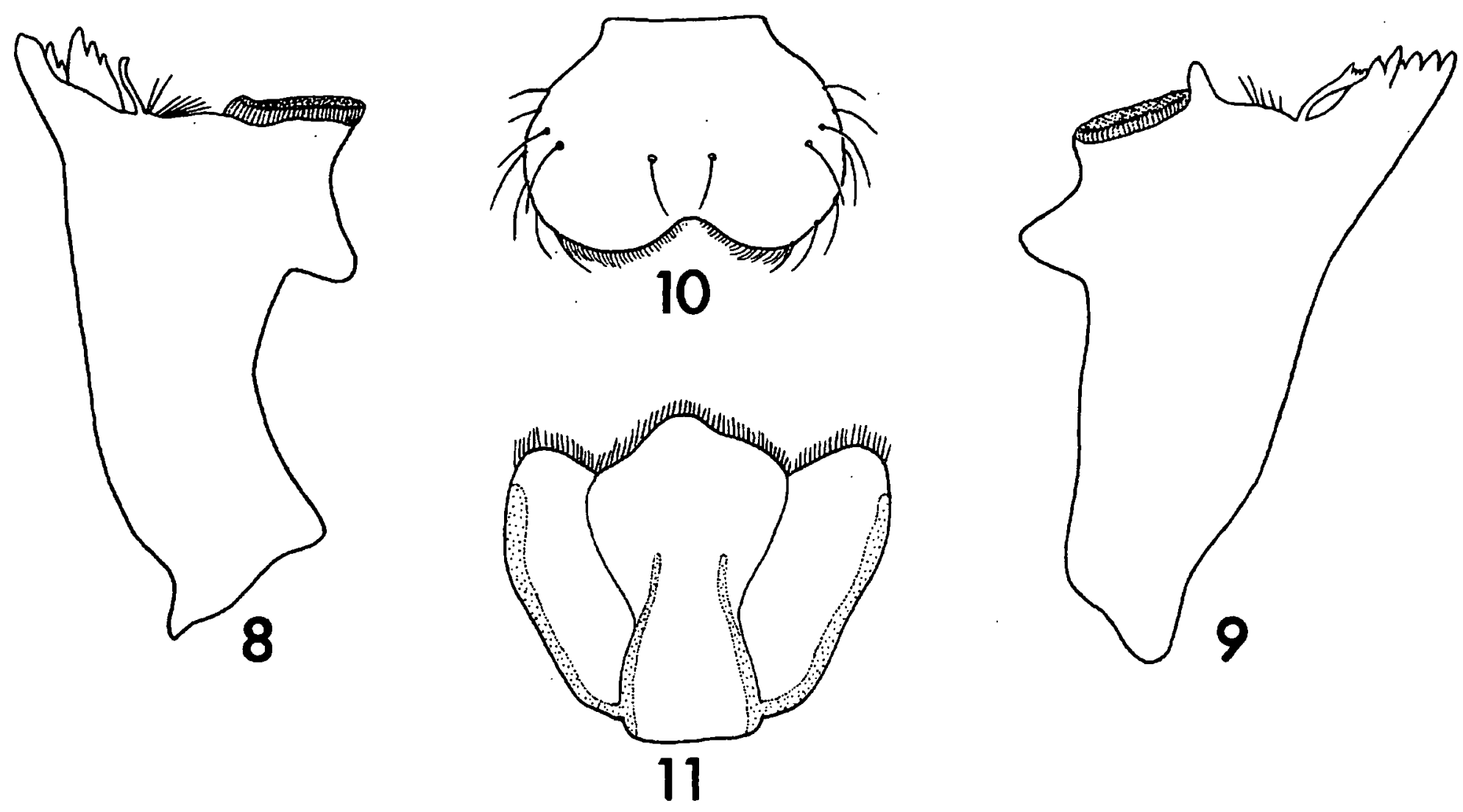

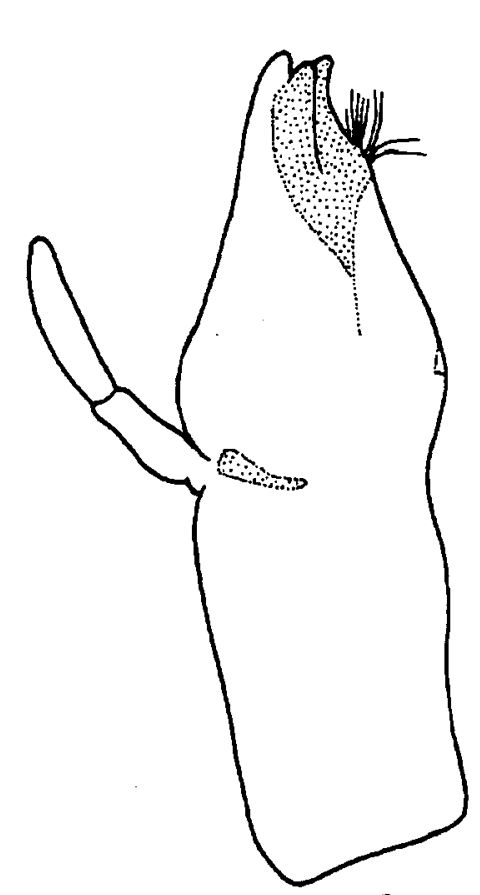

12

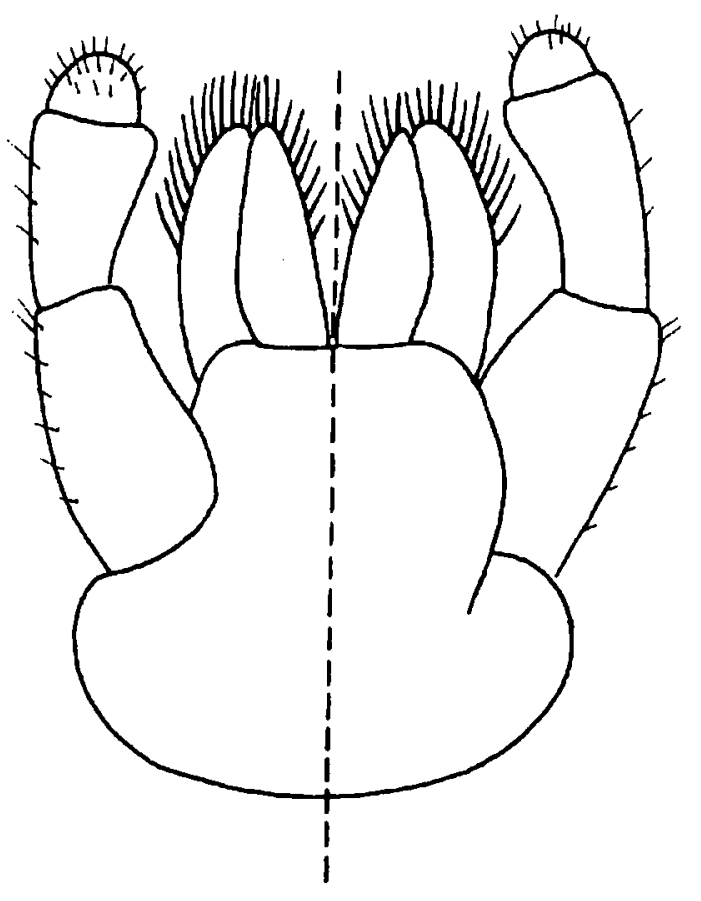

13

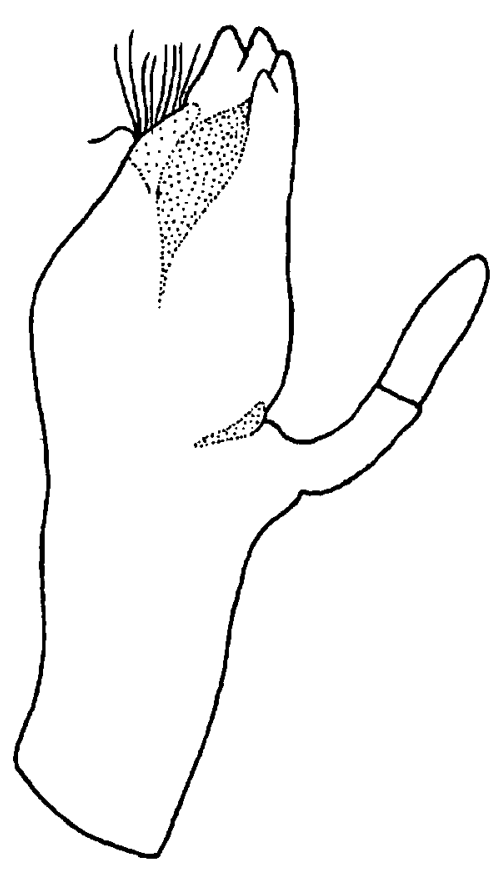

14

Figs. 8-14. Acanthiops tsitsa n. sp., larva. 8 : Left mandible. 9 : Right mandible. 10 : Labrum (dorsal). 11 : Hypopharynx. 12 : Right maxilla. 13 : Labium (left ventral, right dorsal). 14 : Left maxilla.

Figs. 8-14. Larve d'Acanthiops tsitsa n. sp. 8 : Mandibule gauche. $9:$ Mandibule droite. $10:$ Labre en vue dorsale. $11:$ Hypopharynx. 12 : Maxille droite. $13:$ Labium en vue ventrale à gauche et en vue dorsale à droite. $14:$ Maxille gauche. 

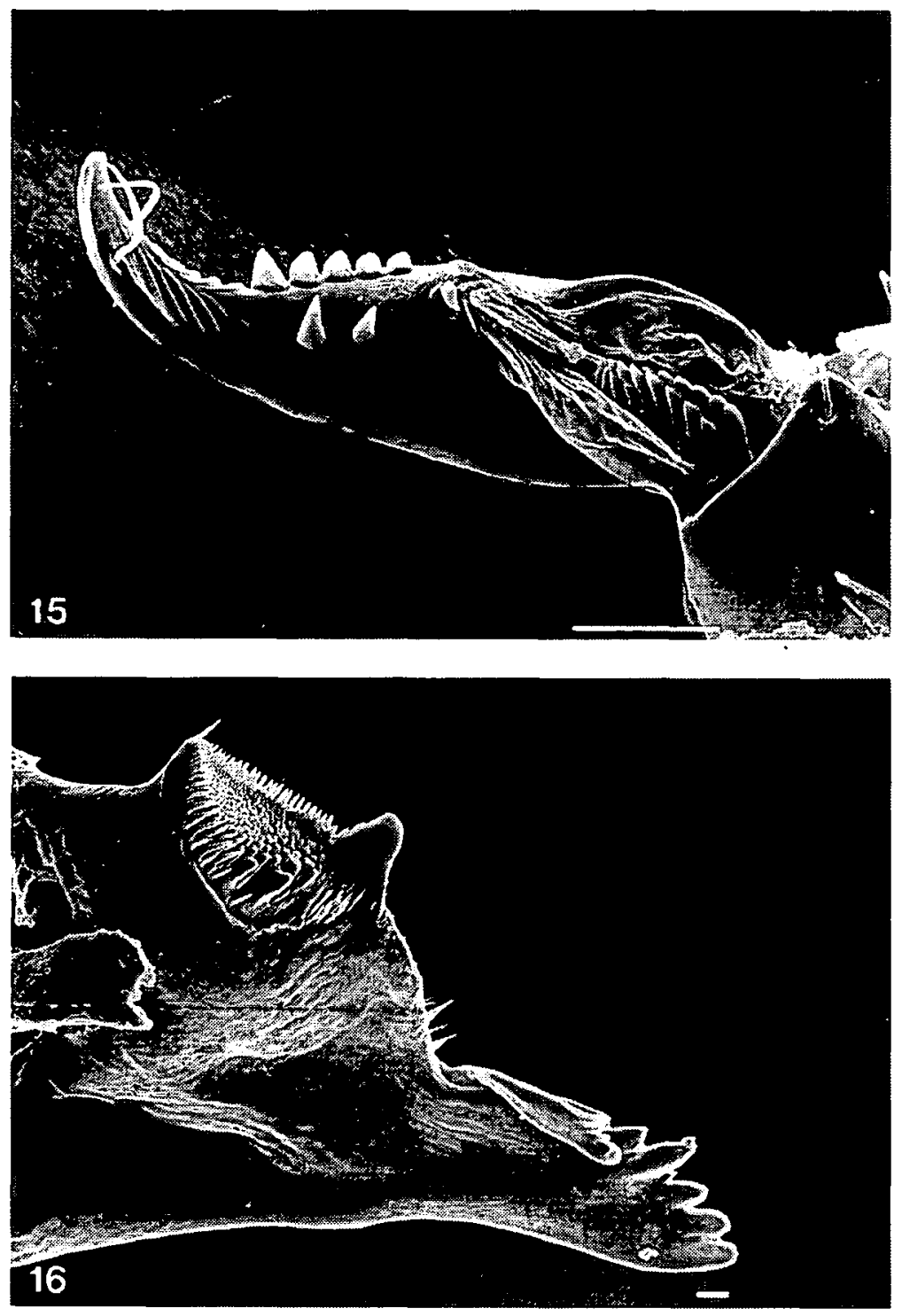

Figs. 15-16. Acanthiops tsitsa n. sp., larva. 15 : Claw, showing double row of denticles and subapical bristles (scale line $=100$ $\mu \mathrm{m}) .16:$ Left mandible (scale line $=10 \mu \mathrm{m}$ ).

Figs. 15-16. Larve d'Acanthiops tsitsa n. sp. 15 : Griffe, montrant la double rangée de denticules et les soies subapicales (échelle = $100 \mu \mathrm{m}$ ). $16:$ Mandibule gauche (échelle : $10 \mu \mathrm{m}$ ).

in A. marlieri from Zaire. This stepwise transition suggests that certain species represent early branches of this monophyletic group while the highly specialized species $A$. marlieri is sister to one or more apotypic species.

We view the phenoclinal relationship of species as compelling evidence for our generic concept of Acanthiops (see Ross 1974). This stepwise transition of species furthermore indicates that the inclusion of all other species than the terminally derived $A$. marlieri in a separate genus or subgenus (i.e., Afroptiloides) would, by definition, result in a paraphyletic classification. On the basis of phenetic differences or by using gap criteria inherent in evolutionary classification (and historically prevalent in mayfly classification), it could be tempting to recognize $A$. marlieri as a separate taxon. However, the morphological disctinctiveness of A. marlieri is essentially due to both the extreme transitional expression of characterization within the clade to which it belongs and its autapomorphies. These are seen in its elongate spines (the most developed), its gills (the greatest degree of asymmetry and overlapping), and the entire loss of setae in the cerci. Based on the obvious phenoclines within the clade, we must regard the absence of the dorsal row of hairlike setae on the femora of $A$. marlieri larvae as a secondary loss and therefore also an autapomorphy within Acanthiops. Our concept of Acanthiops is phylogenetic, and it is our intention, whenever cladistic evidence is available, to apply only strictly phylogenetic classifications in Ephemeroptera (see McCafferty 1991).

Gillies (1990) included Afroptilum bicaudatum Gillies in his subgenus Afroptiloides. Although this species shares a dorsal row of hairlike setae on the tibiae with plesiotypic species of Acanthiops, and reduction of the median caudal filament with all Acanthiops and thus possibly is one of the species now placed in Afroptilum that does share some recent common ancestry with Acanthiops-it does not possess any of the synapomorphies by which we define the monophyletic genus Acanthiops, as elucidated above. Its inclusion in Acanthiops, in our opinion, would overly dilute the genus and compromise its integrity. The relationships and classification of this aberrant species will be taken up elsewhere after more detailed study of its characterization.

Acanthiops and Afroptilum both belong to the subfamily Cloeoninae, based on subfamilial distinctions given by Gillies (1991b) and provisionally recognized by Lugo-Ortiz and McCafferty (1996a). Other than this, and assuming the similarly reduced labial palps were independently evolved, the two appear only distantly related. It should be kept in mind that the genus Afroptilum and subgenus Afroptilum s.s., as they were originally constituted, are polyphyletic (e.g., see Wuillot and Gillies 1994, Lugo-Ortiz and McCafferty $1996 \mathrm{~b}$ and 1996c) and therefore any assessment of the genus must be restricted to its type species, $A$. sudafricanum. Other species that remain in Afroptilum at this time, such as $A$. bicaudatum (mentioned above), will have to be individually reviewed in light of phylogenetic relationships in order to determine their appropriate generic classification. 


\section{Acanthiops tsitsa Barber-James \& McCafferty, n. sp.}

\subsection{Description}

Larva

Body length : $6.5-7.0 \mathrm{~mm}$; cerci length : ca. $4.0 \mathrm{~mm}$. General coloration tawny with dark brown or pale brown markings (Fig. 1).

\section{- HEAD}

With complex pattern on vertex between eyes and posterior to ocelli (Fig. 1).

Antennae (Figs. 1, 3) subequal to width of head, with minute spinelike setae at segment articulations.

Labrum (Fig. 10) relatively deeply notched, with sparse, long, lateral setae, and denser and shorter setae apically; dorsal labral setae with labral formula $1+2$ (see Morihara and McCafferty, 1979).

Maxillary palpi (Figs. 12,14) length approximately one-third length of galealaciniae and not reaching apex of maxillae.

\section{- THORAX}

Thoracic nota patterned more or less as in Figure 1. Pronotum without tuberculation or subsclerotization. Mesonotum without tubercles.

Metanotum with hindwingpads and median tubercle.

Legs (Fig. 6); coxae with proximally expanded lobe, best developed on foreleg; tibiae with row of hairlike setae dorsally.

\section{- ABDOMEN}

Dorsal abdominal pattern more or less as in Figure 1. Terga (Fig. 4) with posterior marginal row of minute denticles and without scales and fine setae; terga 1-8 each with median tubercle, more weakly developed on posterior segments (Fig..2).

Gill lamellae (Figs. 1, 5) moderately asymmetrical, opaque, with dark tracheation, and lacking marginal setation or serration.

Setation of cerci as in Figure 7.

\section{Adult}

Unknown.

\subsection{Material examined}

Holotype : mature larva, South Africa, North East Cape, Tsitsa R. at 3100 '52'S and 28 29'18'E, 1140 m 26-III-1991, H. M. Barber-James and F. C. de Moor, AM (Albany Museum, Grahamstown, South Africa) (Cat. \# ECR 92A). Paratypes : one larval exuviae and mouthparts, gills and legs slidemounted in Euparal, and four larvae, same data and deposition as holotype; five larvae, same data and deposition as holotype except collected 28-III-1993; five larvae, same data as holotype, deposited at PERC (Purdue Entomological Research Collection, West Lafayette, Indiana); five larvae and one larval exuviae, same data as holotype except collected 28-III-1993 and deposited at PERC; four larvae, same data as holotype, deposited at the $\mathrm{Na}$ tural History Museum, London.

Other material examined. One larva, South Africa, North East Cape, Wildebees R. at 31 13'24'S , 28 03'41'"E, 1380m, 26-III-1993, H. M. Barber-James and F. C. de Moor, AM; nine larvae, south africa, North East Cape, Pot R. at $3058^{\prime} 34^{\prime \prime}$ 'S, 28 16'26' E, 1300m, 27-III-1993, H. M. Barber-James and F. C. de Moor, AM.

\subsection{Etymology}

The specific epithet is a noun in apposition from the Xhosa language meaning «the water that comes from the ground» and also is in reference to the Tsitsa River, type locality of the species in South Africa.

\subsection{Remarks}

Acanthiops tsitsa is the second species of this genus described from South Africa. Overall, it appears closely related to A. varius, the larvae of both having relatively poorly developed dorsal armature, and even having generally similar dorsal abdominal color patterns. The two congeners, however, can be distinguished by their dorsal abdominal armature [compare Fig. 2 of $A$. tsitsa with Fig. 7 of Gillies (1991a) of $A$. varius]. In lateral view, the tubercles of $A$. tsitsa are slightly more dorsally oriented and relatively blunt or rounded apically, especially on middle abdominal terga; the tubercle on tergum 8 is very poorly developed, and the tubercle is not developed on tergum 9. In A. varius, tubercles are sharper and not rounded apically and are more posteriorly oriented; also the tubercle is poorly developed on tergum 1 and 9 . In addition, the labra of the two species differ, having a dorsal setal formula (see Morihara and McCafferty, 1979) of $1+2$ in A. tsitsa (Fig. 10) and $1+4-5$ in A. varius [Fig. 2 of Gillies (1991a)]. Other distinguishing mouthpart characteristics of $A$. tsitsa include maxillary palpi that are shorter (Figs. 12,14) than those of $A$. varius [Fig. 1 of Gillies (1991a)], marginal setae of the hypopharynx that are more developed (Fig. 11) than those of A.varius [Fig. 3 of Gillies (1991a)], and terminal labial palp segments that are longer and more distinctive (Fig. 13) than those of $A$. varius [Fig. 4 of Gillies (1991a)].

In rivers where $A$. tsitsa has been collected, larvae were taken in swift currents. In the Tsitsa River, they were found on bedrock, stones, and sedges; in the Wil- 
debees River, they were found on bedrock; and in the Pot River, they were found on bedrock and stones, and amongst marginal vegetation.

\section{Acknowledgements}

We would like to thank Nikki Köhly (Grahamstown, South Africa) for preparation of the figures used herein; F. C. de Moor (Grahamstown, South Africa) for helping to collect specimens of $A$. tsitsa, and discussing the project; R. D. Waltz (Indianapolis, Indiana) for his thoughts on the generic classification of African Baetidae; and Alain Thomas (Toulouse, France) for the French translations. This article has been assigned Purdue Agricultural Research Program Journal No. 14960.

\section{References}

Crass R.S. 1947. - The may-flies (Ephemeroptera) of Natal and the Eastern Cape. Ann. Natal Mus., 11 : 37-110.

Demoulin G. 1967. - Description de deux larves atypiques de Baetidae (Ins. Ephemeroptera), Bull. Ann. Soc. r. entomol. Belg., 103 : 226-232.

Gillies M.T. 1990. - A revision of the African species of Centroptilum Eaton (Baetidae, Ephemeroptera). Aquatic Insects, 12 : 97. 128.

Gillies M.T. 1991a. - A new species of Afroptilum (Afroptiloides) from east Africa (Ephem., Baetidae). Entomologist. mon. Mag., $127: 109-115$.

Gillies M.T. 1991b. - A diphyletic origin for the two-tailed baetid nymphs occurring in east African stony streams with descriptions of the new genus and species Tanzaniella spinosa gen. nov. sp.pp. 175-187 in Alba-Tercedor J. \& Sanchez-Ortega A. (eds.). Overview and strategies of Ephemeroptera and Plecoptera. Sandhill Crane Press, Gainesville, Florida.
Kimmins D.E. 1955. - Ephemeroptera from Nyasaland, with descriptions of three new species and some interesting nymphal forms. Ann. Mag. nat. Hist., $8: 859-880$.

Lugo-Ortiz C.R. \& McCafferty W.P. 1996a. - Aturbina george gen. et sp. n. : a small minnow mayfly (Ephemeroptera : Baetidae) without turbinate eyes. Aquatic Insects, $18: 175-183$.

Lugo-Ortiz C.R. \& McCafferty W.P. 1996b. - Crassabwa : a new genus of small minnow mayflies (Ephemeroptera : Baetidae) from Africa. Annls. Limnol., 32(4) : 235-240.

Lugo-Ortiz C.R. \& McCafferty W.P. 1996c. - The composition of Dabulamanzia, a new genus of Afrotropical Baetidae, with descriptions of two new species. Bull. Soc. Hist. nat. Toulouse, 132 : 7-13.

McCafferty W.P. 1991. - Toward a phylogenetic classification of the Ephemeroptera (Insecta) : a commentary on systematics. Ann. entomol. Soc. Am., 84 : 343-360.

McCafferty W.P. \& de Moor F.C. 1995. - South African Ephemeroptera : problems and priorities : 463-476 in Corkum L.D. \& Ciborowski J.J.H. (eds.). Current directions in research in Ephemeroptera. Canadian Scholars' Press, Toronto.

Morihara D.K. \& McCafferty W.P. 1979. - The Baetis larvae of North America (Ephemeroptera : Baetidae). Trans. Am. entomol. Soc., $105: 139-221$.

Ross H.H. 1974. - Biological systematics. Addison-Wesley, Reading, Massachusetts, $345 \mathrm{p}$.

Waltz R.D. \& McCafferty W.P. 1987. - New genera of Baetidae (Ephemeroptera) from Africa. Proc. entomol. Soc. Wash., 89 : 95 99.

Wuillot J. \& Gillies M.T. 1994. - Dicentroptilum, a new genus of mayflies (Baetidae, Ephemeroptera) from Africa. Aquatic Insects, $16: 133-140$. 